\title{
GEM PEGMATITES OF MINAS GERAIS, BRAZIL: THE TOURMALINES OF THE GOVERNADOR VALADARES DISTRICT
}

\author{
By Keith Proctor
}

The previous article in this series focused on tourmaline production around the city of Araçuaí, in northeastern Minas Gerais, and discussed 20 important mines in that area. The present article turns to the major tourmaline mines in southeastern Minas Gerais, in the broad area surrounding the gemstone capital, Governador Valadares. Specifically, the Cruzeiro, Golconda, Santa Rosa, and Jonas mines-all of which count among the most famous tourmaline mines in the world-are described.

\section{ABOUT THE AUTHOR}

Mr. Proctor is president of Keith Proctor Fine Gems, a wholesale gem import firm, in Colorado Springs, Colorado.

Acknowledgments: The author thanks the following people for their assistance: L. Nercessian, J. Lowell, A. Lucio, Dr. C. Barbosa, J. Saver, H. Stern, Dr. H. Bank, E. Swoboda, P. Bancroft, A. Sabbagh, K. Elawar, and O.J. de Moura. Thanks also go to Harold and Erica Van Pelt for their many pholographs, to Wendell Wilson for art work, and L. Moffett for typing, and to Drs. P. Bariand,

A. Gaines, P. Keller, P. Moore, R. Nash, F. Pough, $J$ S. Shigley, and J. Sinkankas for reviewing and critiquing the original manuscript. Special appreciation goes to Mauna Proctor for her help in translating, typing, and editing, and for her constant support. The many miners and mine owners who were so instrumental in providing information for this series are acknowledged at the end of this article.

Unless otherwise noted in the figure legends, the location photos are by the author. Also, the mineral specimens and cut stones shown in figures $1,3,7$, 8,11 , and 13 are the property of the author.

(C) 1985 Gemological Institute of America
A lthough hundreds of mines in the broad region north, east, and southeast of Governador Valadares have produced tourmaline, four major deposits account for most of the production in this area: Cruzeiro, Golconda, Santa Rosa, and Jonas. Not only have these mines been the source of millions of carats of fine blue, green, red, and multicolored tourmaline, but the very human stories that surround their major discoveries have achieved the status of legends in only a few short years. A single pocket in the Jonas mine, for example, found after months of backbreaking work by a few determined miners-and only days before mining was to cease for lack of funds-yielded hundreds of kilograms of fine gem- and specimen-quality "cranberry"-red tourmaline; a second pocket yielded only one superb crystal (figure 1).

This third article in a series on the gem pegmatites of Minas Gerais (see Proctor, 1984, for part 1-on the overall history, geology, and mining of the region as well as the major aquamarine deposits; and Proctor, 1985, for part 2-on the tourmaline deposits of the Araçuai districts) describes these four major pegmatite areas of the Governador Valadares region and the great variety of fine gem tourmalines found there. The history of these mines and the major finds associated with each are discussed, as are the occurrence of the gem material, the gem deposits themselves, and past and potential production. Other mines in this area are also identified; the reader is referred to the map in figure 2 for the localities of the most notable deposits.

\section{CRUZEIRO}

The Cruzeiro pegmatite deposit is one of the largest and most consistent producers of tourmaline in the world. It is particularly noted for the fine green tourmalines found there (figure 3). The mining region is reached via BR-116, a paved road that connects Governador Valadares with 


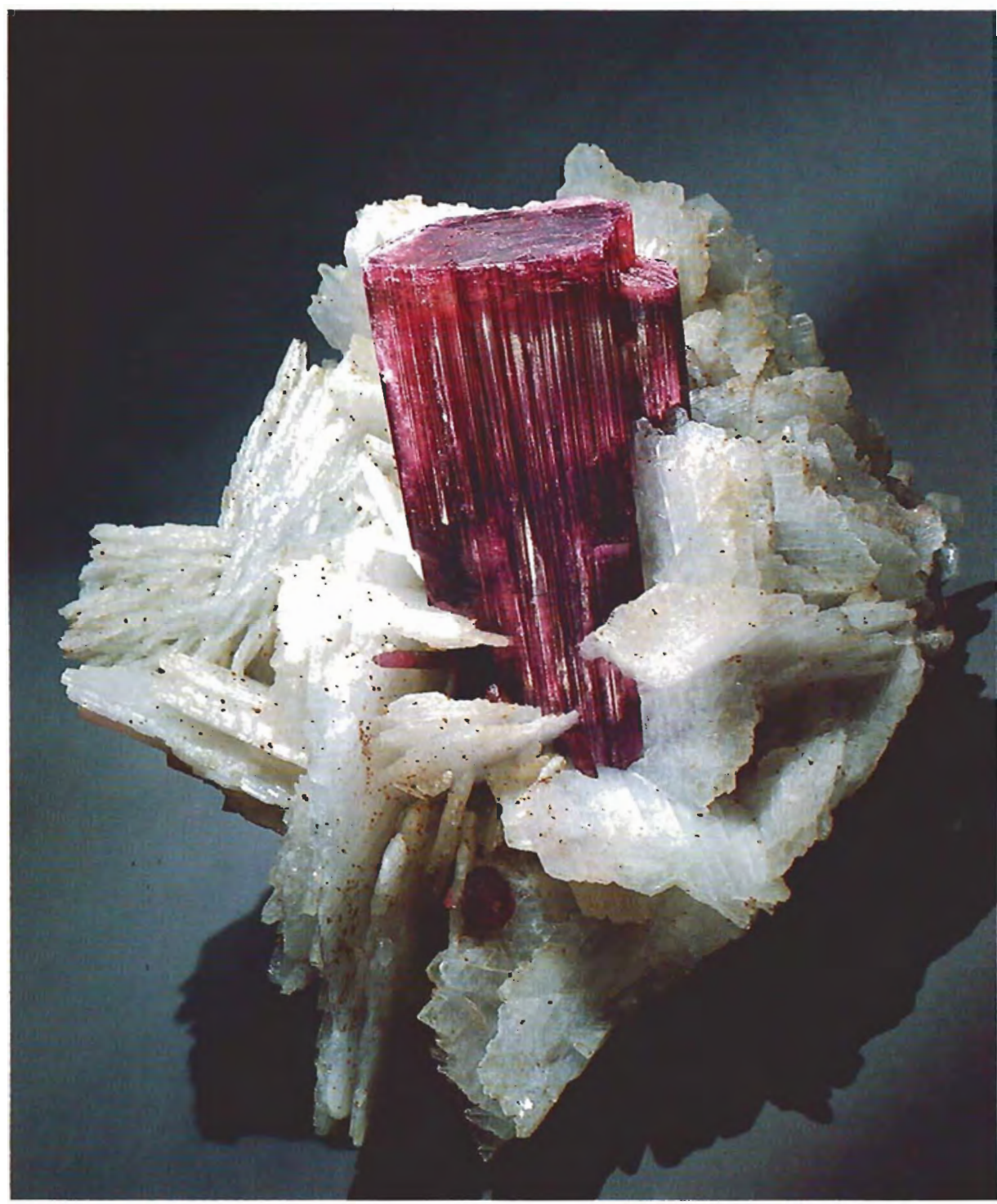

Figure 1. The Rose of Itatiaia, a $35 \times 12-c m$ rubellite crystal with cleavelandite, was the only specimen taken from the second pocket of the legendary Jonas mine, one of the principal deposits of the Governador Valadares district. Photo (c) Harold e) Erica Van Pelt.
Teofilo Otoni to the north (again, see figure 2). After proceeding $43 \mathrm{~km}(27 \mathrm{mi}$.$) north from$ Governador Valadares, turn at the village of Frei Inocencio onto a dirt road that leads northwest for $53 \mathrm{~km}$ to the village of São José da Safira. From there, a narrow, steep, barely passable road takes you up the mountain for $12 \mathrm{~km}$ to the main mine offices. The pegmatites are on the east slope near the top of a long north-south-trending range called the Serra Safira (after the "sapphire" blue tourmalines that were found here by early explorers). The range divides the watersheds of the Rio Sauçuí Grande and its tributary the Rio Urupuca (Cassedanne and Sauer, 1980).

History. The mountains in the Serra Safira range are undoubtedly the "Emerald Mountains" dis- covered by Paes Leme during his 1674 expedition (Proctor, 1984). In 1914, deposits of green and blue tourmalines were rediscovered and primitive mining was begun; a few magnificent crystals were produced and cut as gemstones (Bank, 1979; Lucio, 1980). However, full-scale commercial mining at Cruzeiro began not with tourmaline but with mica.

Because of their richness in electronic-grade mica, pegmatites in this region were mined as early as World War I, with the first formal mining concession granted in 1916. In 1933, the German export firm of Werner, Frank \& Cia. hired Dilermando Rodrigues de Melo to secure mica properties and commence mining in the district around Figueira do Rio Doce, a small (approximately 1,000 inhabitants) village that grew into the present city 


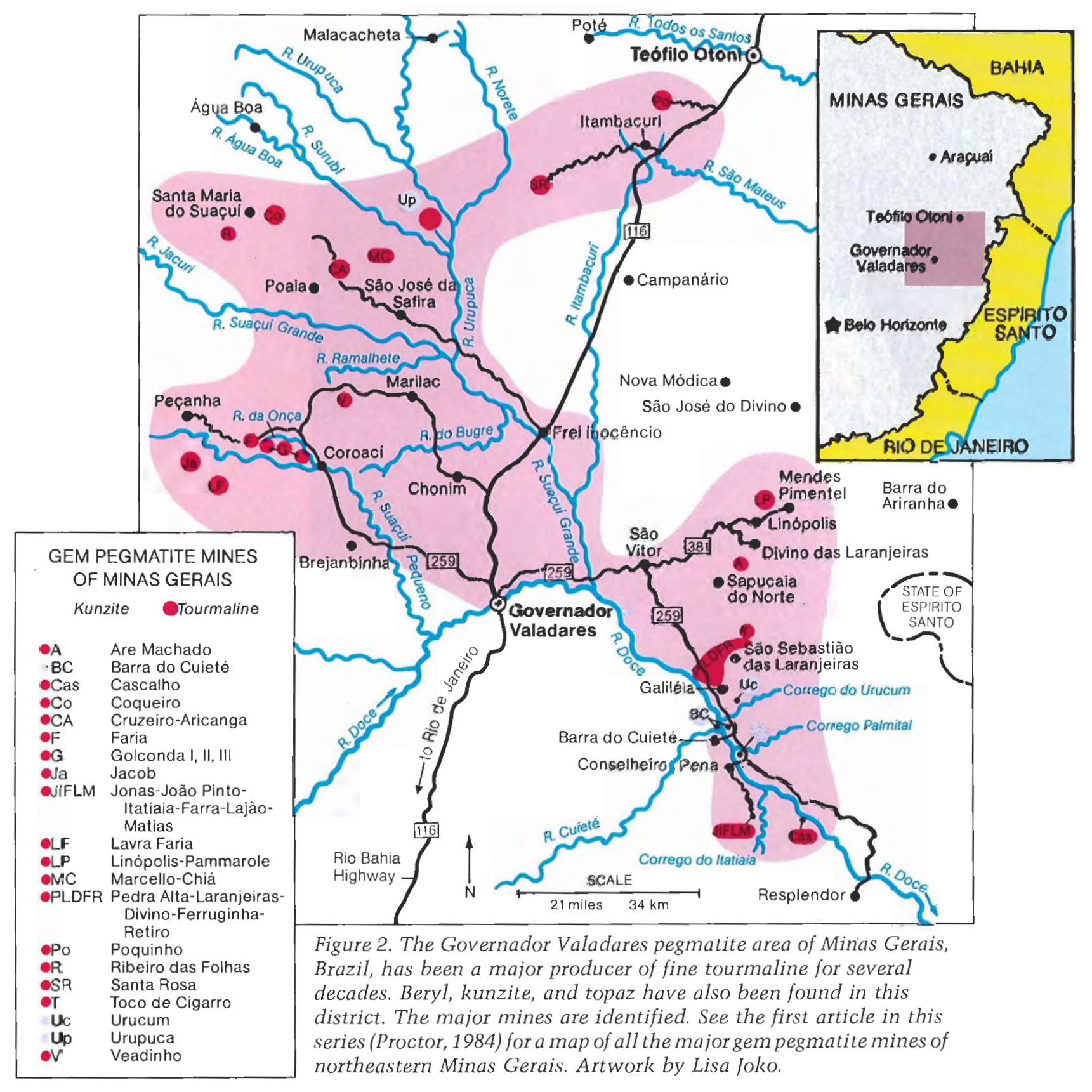

of Governador Valadares. During World War II, control of Cruzeiro passed to Rodrigues de Melo, and the government of Brazil invited technical experts from the United States to help increase production of this extremely valuable wartime mineral commodity. During the war, when the mica was at peak production, 600-800 garimpeiros worked more than 40 locations in the pegmatites (Sauer, 1975). Ultimately, the Cruzeiro region provided $12 \%$ of Brazil's entire wartime production of mica (Ottoni and Noronha, 1942; Barbosa, 1944; Murdock and Hunter, 1944). Details on the
Cruzeiro pegmatites and over 200 other potential gem mines in this area are provided by Gonsalves (1949) and Pecora et al. (1950a). Even today, when the Cruzeiro deposits are more famous for their gemstones than their mica, it is the mica that pays for the entire mining costs and for the most part supports the inhabitants of the small village of Cruzeiro, which lies just above the main mine, high on a ridge of the Serra Safira (figure 4). Ironically, while the Americans were exploiting the mica during the 1940s, the German gem dealers came down from Teofilo Otoni and purchased tons 
and tons of gem tourmaline crystals that were produced incidentally (L. Nercessian, pers. comm., 1984).

Although mining at Cruzeiro decreased sharply after the war, the "rediscovery" of large, fine tourmaline crystals in the 1950s led to renewed mining activity and signaled the beginning of the "modern" period of Cruzeiro's development. At present, the major portion of the Cruzeiro property is owned by Jose Neves, but one end of the 1300-m-long pegmatite area, located on the brow of the mountain ridge, is owned and aggressively mined by the Aricanga Company.

Occurrence. The Cruzeiro "mine" actually consists of several individual mines that exploit three more or less parallel, largely unweathered granitic pegmatite bodies that are simply called the No. 1, 2 , and 3 bodies. All three bodies have been mined for gemstones, although No. 1 has been the most productive.

These three vein-like pegmatite bodies strike approximately $\mathrm{N} 20^{\circ} \mathrm{W}$, and dip steeply SW. Along with śeveral minor side veins, they intrude a layer, several hundred meters thick, of quartzite (a rarity in this region) and mica schist. In places the veins are only a few meters thick, but elsewhere they widen to as much as $55 \mathrm{~m}$ (180 ft.). The

Figure 3. This ring (11.83 ct) and pendant $(16.5 \mathrm{ct})$, together with the 12.5 - cm (5-in.) crystal also shown here, represent some of the fine green tourmaline found at the Cruzeiro mine. Jewelry created by Bud Stafford, Stafford-Kay Jewelers, Colorado Springs, CO.

Figure 4. The entire village of Cruzeiro (note the cross in the foreground, from which the village and mine get their name) is pictured here, isolated along this ridge of the Serra Safira. Photo by Peter Keller.

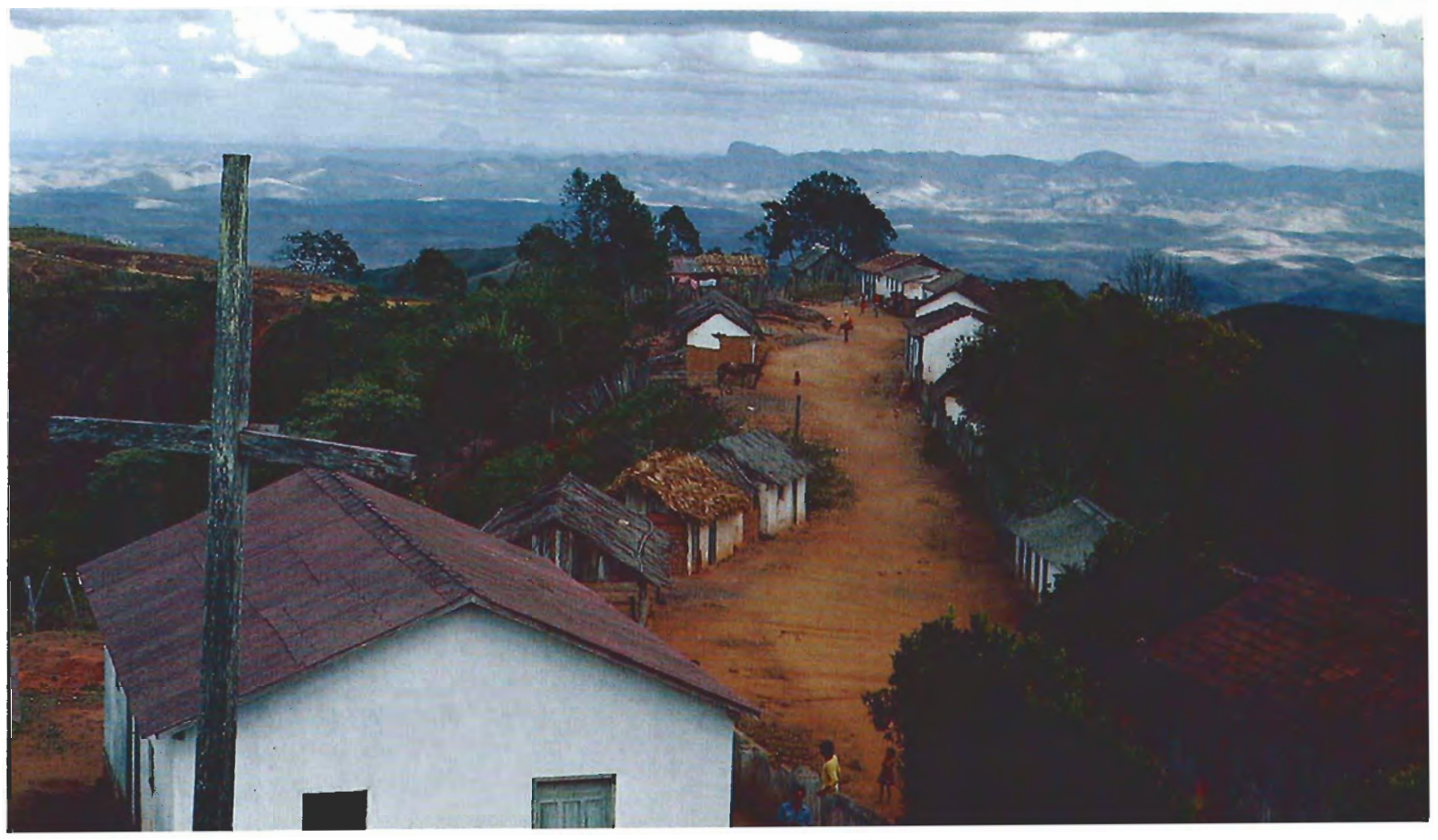


Cruzeiro pegmatites are classic examples of internally zoned complex pegmatite bodies. The zoning is similar to that shown diagrammatically by Shigley and Kampf (1984, pp. 70 and 71; see also Cassedanne and Sauer, 1980): a muscovite, quartz, and feldspar wall zone, with a quartz-microcline-albite intermediate zone. The gem crystals are usually found in the intermediate zone and occasionally in the peripheral part of the core zone. This pocket region on the margin of the core contains lepidolite, milky quartz, large microcline feldspars, and albite. Pockets in this region frequently contain superb gem tourmaline crystals and occasionally l-m-long altered spodumene crystals.

Many opaque to transparent green, blue-green, and pink tourmaline crystals, some of them 10-25 cm (4-10 in.) long, have been found. The tourmalines occur both in groups and as freestanding single crystals attached to the pocket wall. Although the latter are much less common, they are frequently the most gemmy. As an indication that gem pockets are close by, miners watch for the presence of bladed albite (cleavelandite), lepidolite associated with black tourmaline, and dark coatings of iron-manganese oxides or phosphates on quartz and other minerals. It is interesting to note that gem-quality tourmaline is usually found

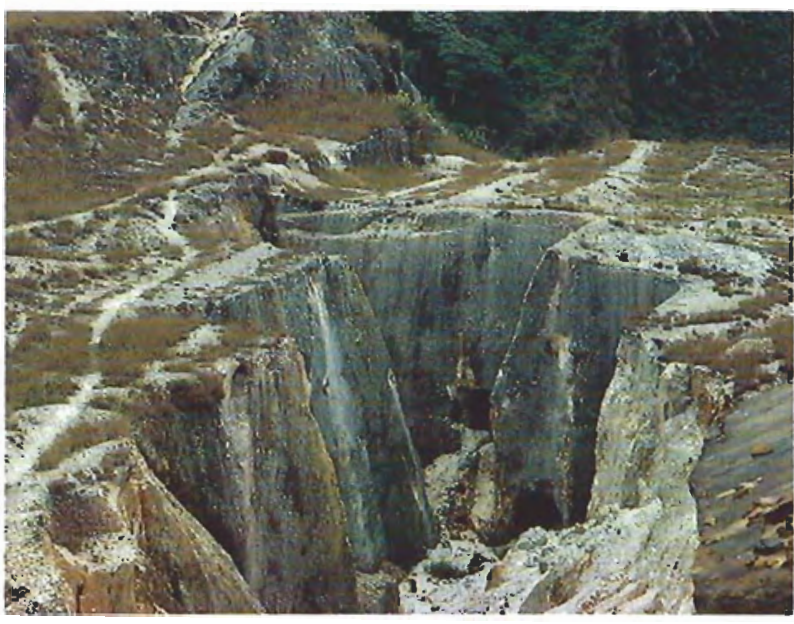

Figure 5. Open-pit mining is commonly used in some of the wider sections of the Cruzeiro vein. Note the two tunnels that follow the vein in to the quartzite wall of this open pit. Photo by Peter Keller.

associated with albite but not with microcline, which indicates that the first two formed together.

Massive nongem garnet occurs in the Cruzeiro pegmatite, as do large nongem beryl crystals and such rarer minerals as amblygonite, torbernite, phosphuranylite, coeruleolactite, columbite-

Figure 6. A garimpeirostands in the doorway of his mudand-stick hut, near the entrance of one of the many tunnels driven throughout the Cruzeiro region.

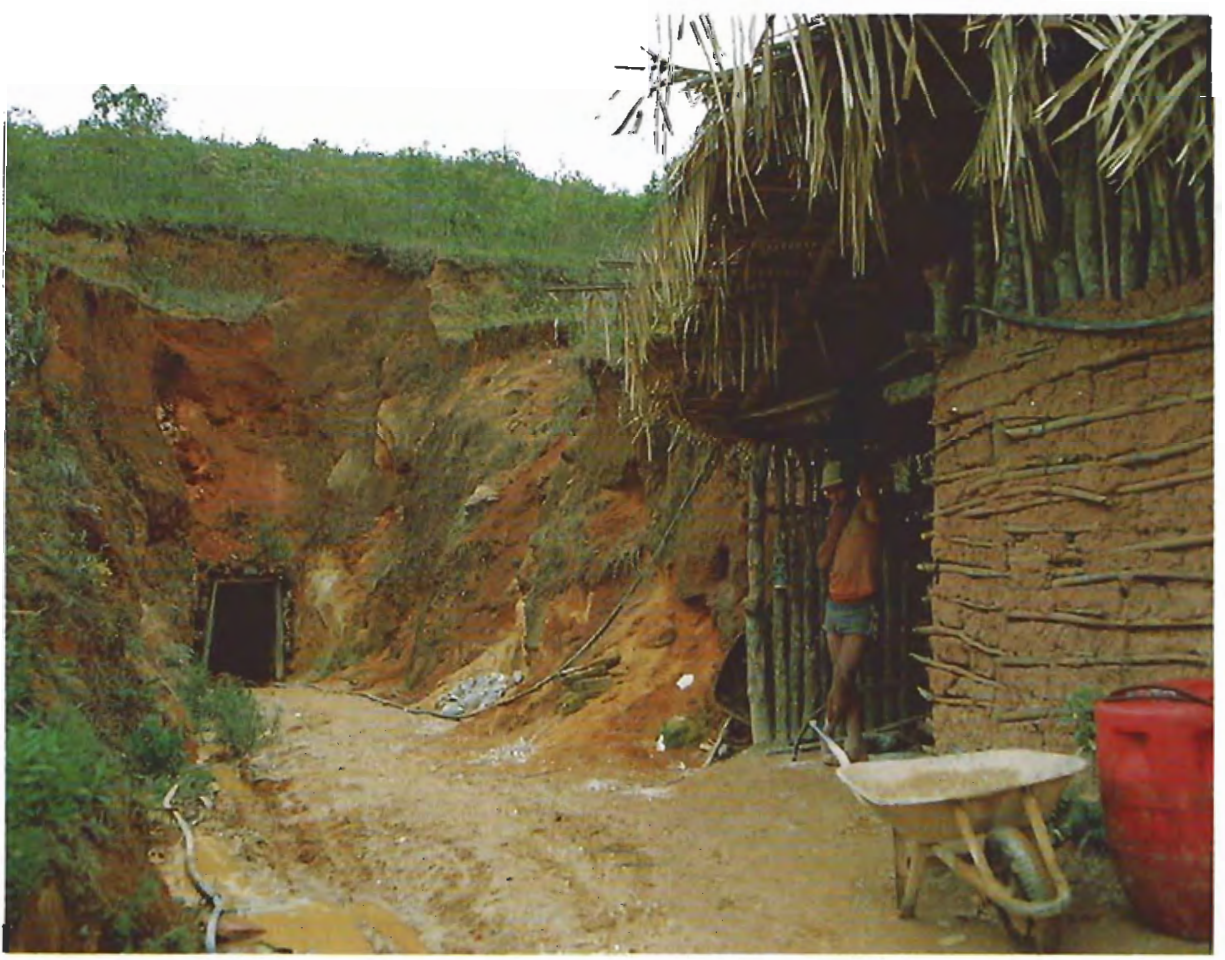




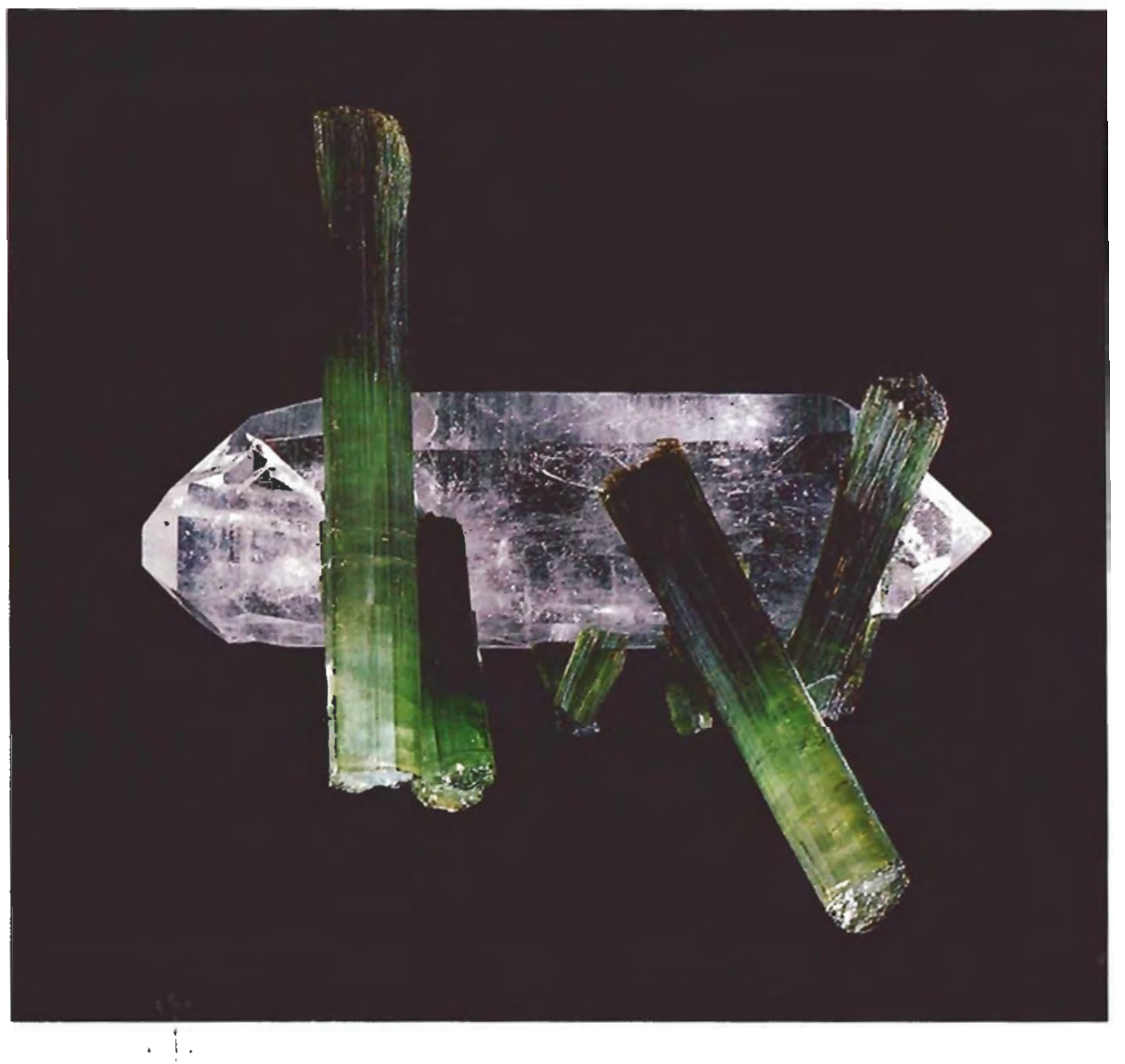

Figure 7. Elongate green tourmaline crystals on quartz from the Cruzeiro mine. The specimen is $16 \mathrm{~cm}$ wide $\times 12 \mathrm{~cm}$ high $(6.5 \times 43 / 4$ in.). Photo $\mathbb{C}$ Nelly Bariand.

tantalite, and cassiterite. These minerals indicate that the solutions that formed the Cruzeiro pegmatite were especially rich in lithium, boron, beryllium, manganese, tin, niobium, tantalum, phosphorus, uranium, and even copper.

Although most mining throughout this pegmatite region is via tunnels, open-pit mining is used in some of the wider sections of the veins (figure 5). Several major tunnels enter the hillside through quartzite or schist near the top of the mountain at an altitude of $1100-1200 \mathrm{~m}$ (Sauer, 1975). Presently, though, most of the mica tunnels driven during wartime and many of the gemstone tunnels have caved in or are filled with waste. The few tunnels that are still open traverse the body in random fashion and generally are small, narrow exploratory openings (figure 6). Parts of the Aricanga Company mine have been weathered to a soft, altered kaolin that the miners can dig with their bare hands or using only primitive tools (Baker, 1975).

The Cruzeiro Gems. Cruzeiro is famous for its gem-quality and specimen-grade tourmaline crystals, including fine blue-greens and pinks, near"emerald" greens called chromolites, and fine blues (indicolites). The gems cut from the blue and green material are usually eye clean. At times, superb red tourmalines (rubellites) have been found in crystals $5 \mathrm{~cm}$ (2 in.) or more in length: some are among the best ever produced in Brazil. Especially notable are the popular green-and-pink bicolored gems called "watermelons," although these are commonly heavily included.

Diversity in crystal habit and coloration is characteristic of the tourmaline crystals from the Cruzeiro deposits. Some crystals are long and thin (figure 7), and others are thick, short, flatly terminated prisms (as shown in Keller and Kampf, 1977, figure 7). Still others have a black, almost velvety termination. Some of the finest crystals of stubby habit and flat termination exhibit the dark rose to red tint characteristic of Cruzeiro rubellite and may weigh several kilograms each/Cassdanne and Sauer, 1980).

Production. Cruzeiro is probably the most consistent gem-producing region in Brazil. For 15 years, from 1955 to 1970 , the Cruzeiro mine produced an average of $200 \mathrm{~kg}$ (440 lbs.) of crystals per week, although usually only 1 or $2 \mathrm{~kg}$ of the weekly total was gem-quality tourmaline. The overall produc- 
tion of tourmaline at the Aricanga mine has been somewhat less, but a much greater proportion of the tourmalines found there have been gem quality.

Major pocket finds at Cruzeiro are almost too numerous to mention. In 1966, for example, a superb rubellite crystal was taken from a hard-rock pocket that contained no other gem-quality crystals. This 14-kg deep red crystal cut 10,000-12,000 ct of very clean stones. In 1968, over 2,000 kilos of largely opaque crystals of fine green color were removed from a single pocket. These crystals were used worldwide for carving and as mineral specimens. In mid-1971, in one of Brazil's largest rubellite finds, 400 crystals were taken from several pockets. This was the find that established Cruzeiro as one of Brazil's premier rubellite mines.

The most impressive find at the Aricanga mine occurred in 1982, when a big pocket yielded over $700 \mathrm{~kg}$ of mostly clean tourmaline "pencils," $90 \%$ of which were a nice green with the rest bluegreens and reds (L. Nercessian, pers. comm., 1984). Many kilos of fine rubellite and specimen-quality green tourmaline were found at the Cruzeiro as recently as 1983 and 1984, respectively. Because of its size, Cruzeiro (including the Aricanga mine) will probably continue to produce consistently for several more decades.

\section{GOLCONDA}

Among the best known and most productive pegmatite mines in Minas Gerais are the three Golcondas, which are located within $5 \mathrm{~km}$ of one another northwest of Governador Valadares (see figure 2). The two newer Golconda mines (II and III), in particular, are noted for having produced some of the finest green tourmalines and blue tourmalines to emerge from Brazil, as well as some unique bicolored crystals (figure 8). The Golconda mines are reached by taking highway BR- 116 north from Governador Valadares approximately $3 \mathrm{~km}$, turning off to the northwest at the road to Coroaci, (\#259) and proceeding $33 \mathrm{~km}$ to the Golconda II, which is located on the headwaters of Onça Creek. Golconda I lies $4 \mathrm{~km}$ east, and Golconda III $1 \mathrm{~km}$ northwest, of Golconda II.

History. Golcondas I and II. The original Golconda, named after the famous diamond city of ancient India, has been operated as a mica mine since its discovery in 1908; it is one of the oldest pegmatite mines in Brazil (Pecora et al., 1950b). It is such a large pegmatite that at times over the years it has produced significant quantities of gem rough.

Golconda II was opened in 1935, when foreign interests first exploited it for mica. Since World War II, notable deposits of gem crystals, including green, blue, and rose tourmaline and small quantities of morganite, have been produced by Golconda II, which, like Golconda I, is an immense pegmatite body. Fifty kilograms of "sapphire"-blue "pencils" were found here in 1968. Most of the stones produced were of the finest pure blue color, which established Golconda II as one of the premier sources for fine indicolite.

However, the Golconda mine so fabled in the tourmaline mining lore of Minas Gerais is a small hillside deposit, Golconda III. In 1961, a single immense "pocket" found at Golconda III yielded $900 \mathrm{~kg}$ (about one ton) of the choicest "emerald"green gem tourmaline crystals ever discovered in Brazil. This harvest of crystals yielded gems of a quality so high that they set standards of color and clarity by which dealers in Brazilian gems still measure all other green tourmaline.

Golconda III. The history of Golconda III began in 1961 on a small farm owned by José Menezes Zequinha. A small hill was the dividing line between his farm and that of his neighbor, Pedro Espirito. One day, Zequinha began digging a few small tunnels in a pegmatite outcrop on his side of the hill and almost immediately ran into white kaolin. Whenever they had free time, he and his family kept digging in the kaolin vein, which became wider and wider as they progressed toward the center of the hill. Within a month they discovered a great profusion of beautiful gem tourmaline crystals buried in a large body of soft, solid kaolin deep inside the hill. In a bonanza never before experienced in Brazil and experienced only once since, the entire Zequinha family harvested an average of $35 \mathrm{~kg}$ (80 lbs.) of virtually flawless crystals each day for the first 10 days. As they feverishly continued digging, their kaolin "room" kept getting bigger and bigger.

On the 11th day, when word of the discovery had finally gotten out to all of the local gem dealers, Zequinha's neighbor Espirito found out what was going on. He realized that part of the deposit was probably on his land, and he and his family immediately started digging from their side of the hill. Within a few days they hit the other side 
of the same "pocket," and the two families feverishly worked toward each other. When both families eventually broke through into the same area, great fights erupted over crystals, with each family claiming that the other was in their private territory. Garimpeiros were brought in by both sides so that each could claim as many crystals as possible, and within two months the pocket (which eventually measured $12 \mathrm{~m}$ long $\times 4 \mathrm{~m}$ wide/ was totally cleaned out.

The crystals were the perfect shape for cutting stones in the 6-15 ct range; for the most part they were flawless and, incredibly, of virtually identical color throughout the pocket. Bracelets and necklaces of matched stones could be assembled easily. Most importantly, the color of the cut stones more closely approached "emerald" green than any other large deposit of tourmaline crystals ever found. The total pocket probably yielded over two million carats of finished gemstones $(2.5-3.0 \mathrm{ct}$ per gram of rough).

In 1963, after two years of intensive digging, another major find occurred in hard-rock pegmatite 150 m from the original "pocket" and $20 \mathrm{~m}$ deeper in to the hill. This deposit yielded another $450 \mathrm{~kg}$ of totally clean "pencils" similar in size to the first crystals but with some yellow. It took almost two years to completely clean out this deposit; $80 \%$ of the rough was exported to IdarOberstein (K. Elawar, pers. comm., 1985).

Another deposit that encompassed a number of small pockets was found at Golconda III in 1967 in hard-rock pegmatite in the lower part of the hill. The harvest was a considerable number of distinctive collector specimens: beautiful rose tourmaline crystals tipped in green on a matrix of cookeite (again, see figure 8). After the 1967 strike, Levon Nercessian bought the Espirito farm and rented the Zequinh a farm, but all of his tunneling since then has produced no major finds.

Occurrence. Little is known about the Golconda III body. Although the original 1961 deposit at Golconda III was found in a large kaolinized body, the subsequent discovery of two hard-rock pocket groups deeper within the same hill suggests that the original kaolin mass was probably a secondary, eluvial deposit.

The dike-like Golconda II pegmatite body forms a series of ridges of considerable height, with deep valleys where mining and subsequent erosion have exposed large areas of the pegmatite body.

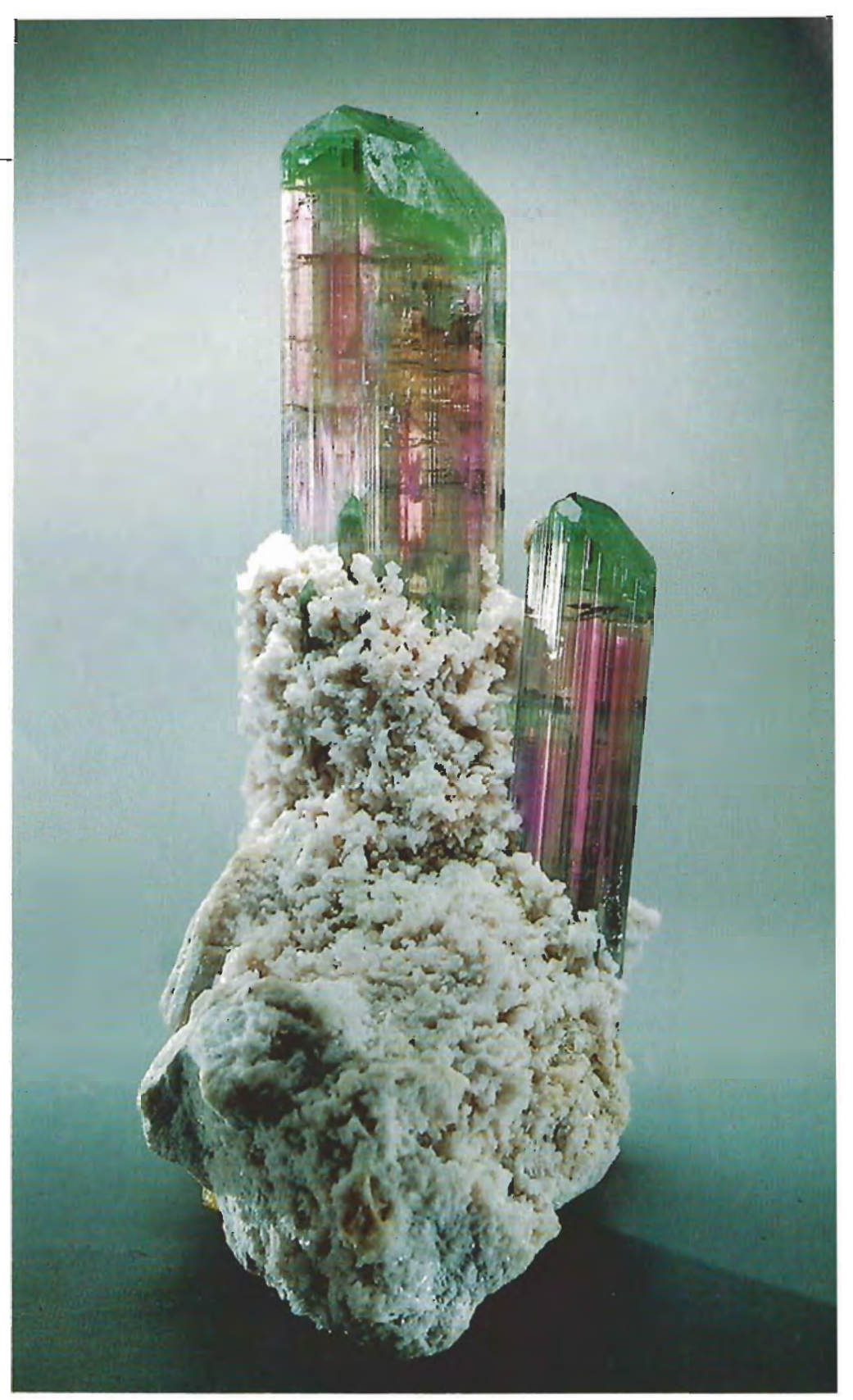

Figure 8. These bicolored tourmalines, rose shafts tipped with green on a cookeite matrix, are characteristic of the Golconda mine. The longest crystal is $8 \mathrm{~cm}$. Photo (C Harold $€$ Erica Van Pelt.

Where exposed, the body appears to be about $60 \mathrm{~m}$ (200 ft.) wide and has been traced along the outcrop to a distance of $400 \mathrm{~m}$ but may be as much as $700 \mathrm{~m}$ long. The strike is $\mathrm{N} 20^{\circ} \mathrm{E}$. The pegmatite appears to be a single sheet, but Ailton Barbosa (one of the current owners of the Golconda II) claims that there are actually two bodies (pers. comm., 1983).

The pegmatite body is intruded into schist and forms the foundation of a large hillside (figure 9). Most of the pegmatite is hard feldspar, but softer areas, rich in albite, have been the source of many gem pockets (figure 10). 
Golconda II has been sporadic, the renovation of this mine by its current owners suggests great promise for the future. Small quantities of fine blue $(150 \mathrm{ct})$ and low-quality green $(50 \mathrm{~kg})$ crystals have been found in the last two years.

\section{SANTA ROSA}

Noted in gemological circles for the fine bicolored (pink and green) tourmaline found there (figure 11), the Santa Rosa-like the Cruzeiro and Golconda mines-was first worked for mica. Located in a primitive area $36 \mathrm{~km}$ southwest of Itambacurí (see figure 21, it can be reached only by traveling an extremely rough dirt road that is totally impassable during the rainy season.

History. The mica mine, which opened in 1938, was abandoned after World War II. However, on October 12, 1967, garimpeiro Tiao Matias noticed chips of colored tourmaline in a series of ant holes and armadillo burrows while prospecting the Santa Rosa hillside. In a race against the ants, he first dug out druses of tourmaline and then, going deeper, found a mass of quartz crystals encrusted with gemmin pink and green bicolored crystals. This strike remains the most important in the mine's history. In less than one year, literally tons of gem- and specimen-quality tourmalines were recovered.

Because much of the pegmatite was totally altered, with the hard "pocket" crystals of tourmaline and quartz buried within soft kaolin, virtually no investment in equipment was needed. Matias found it easy to gather together a group of fellow miners to work, under his "control," what he believed to be the choicest area. Matias allowed no guns, knives, or hard liquor, and promised imprisonment to thieves. But he was far too optimistic about his ability to control when such riches were at stake. Within weeks, as word of the strike spread, the entire kilometer-long hillside was overrun by more than 4,000 garimpeiros (Pough, $1968 \mathrm{a}$ and b). Itambacuri became the center of furtive bargaining between these independent miners and the buyers that came from all over the world (Bancroft, 1984).

Dr. Fred Pough, who visited the mine only nine months after the initial discovery (1968a and b), provides a vivid account of the completely disorganized and wasteful mining that quickly riddled this kaolinized pegmatite and probably left as much gem material behind as was extracted:

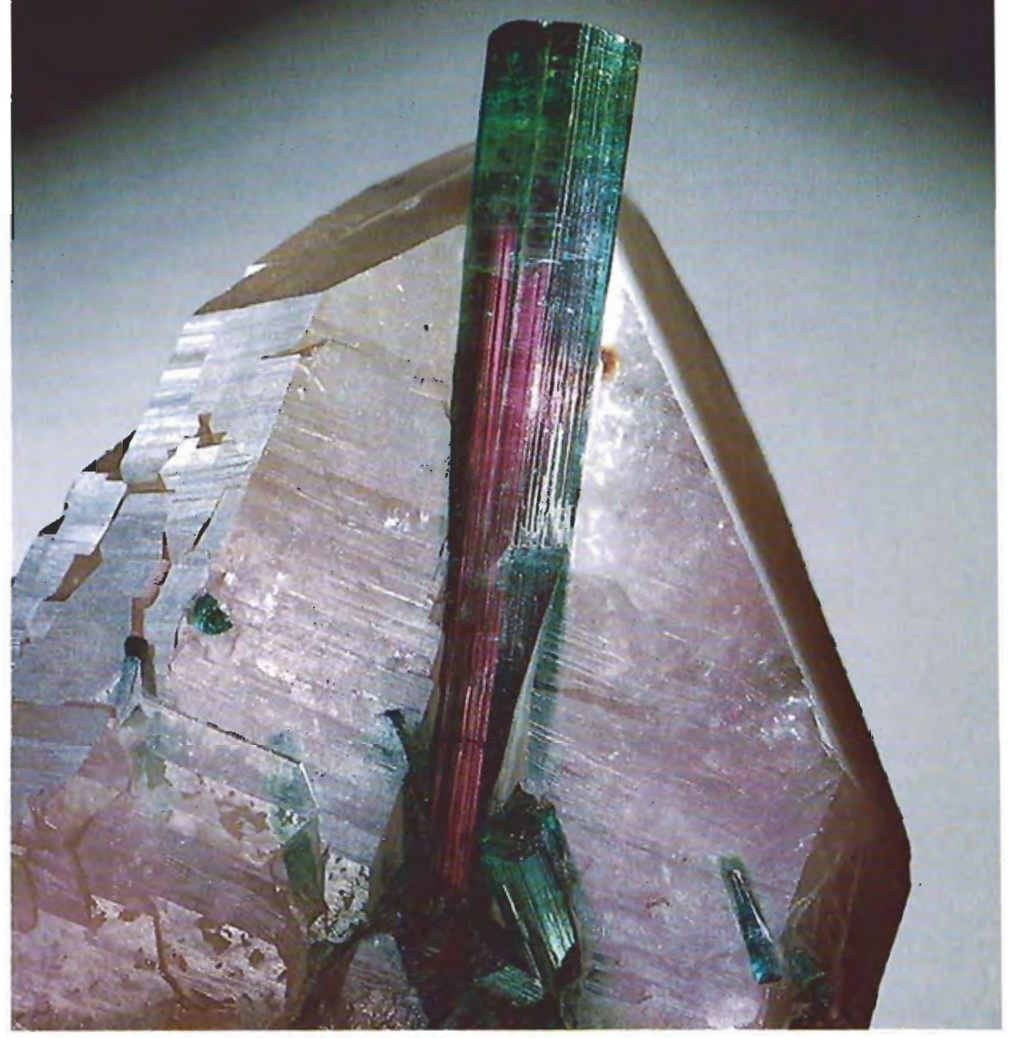

Figure 11. This Santa Rosa mine "watermelon" tourmaline crystal on quartz illustrates the rose center sheathed in green that is characteristic of this locality. This crystal measures $10 \mathrm{~cm} \times$ $1.25 \mathrm{~cm}(4 \times 1 / 2$ in.). Photo (c) Harold 4$)$ Erica Van Pelt.

Since the pegmatite rises through the hill, the tunnels have been started in from the sides, and . . run in horizontally a few meters or tens of meters until they intersect the wall of the pegmatite. As is almost universal in this part of Brazil, weathering has so decomposed the rocks near the surface that most of the digging is through earth, and the tunnels, often unshored, are not very secure. The advent of a real rainy season will probably cause havoc and might well be the end of the mine. Timbering is held to a minimum, for suitable wood is scarce and Brazil's garimpeiros are not really [professional] miners. ... On the day of our visit we saw one badly lacerated man [who had been] hurt in a cave-in. ... .

What do they do when they get to the pegmatite? Well, what can they do, with another tunnel right alongside, probably one above and another just below-or about to be? Nothing! They can scratch out any quartz and tourmaline they happen to encounter in the face of their drift and they can go on into the pegmatite until it becomes barren (presumably the core) and they can cheat a little by bulging their tunnel as much as they dare, 
and then they quit, perhaps to go and start another tunnel somewhere else. . . . No attempt seems to have been made to sink shafts or pits from the summit. In any case, the outcrop is now blanketed with a town. Once they hit the pegmatite, the group working the tunnel is not necessarily instantly rich. Many workers have already moved on to greener fields, for of all the 452 tunnels, only six were producing at the time of our visit, and the 4,000 miners have diminished to 1,000 .

Eventually the miners moved into the hardrock pegmatite that encompasses much of the Santa Rosa hill. Interestingly, the hard-rock tunnels yielded fewer tourmalines, of which a much smaller proportion ( $1 \%$ to $2 \%$ ) were gem-quality, than the original colluvial deposits (L. Nercessian, pers. comm., 1985) The greatest activity at Santa Rosa lasted only five months; within three years the mine was virtually abandoned.

Occurrence. As you approach the Santa Rosa area from Itambacuri, the first indication of the frenetic mining that went on there are the red and white piles of dirt and clay-hauled from a myriad of tunnels - that completely dot the hillside (see figure 12). The hill has been honeycombed by tunnels driven in from both sides to intersect what must be a sheet-like pegmatite rising fairly vertically through the hill. Relatively short tunnels were required to mine the "front side" (as you approach from Itambacuri) because the weathered (collu- vial) deposit is so near the surface (again, see figure 12). However, the "backside" of the hill, with its strike parallel to the elongation of the hill, contains several tunnels 200 to $300 \mathrm{~m}$ long, which penetrated the hard-rock primary pegmatite. The geologic environment of the initial find, which was on the "backside," is similar to that of the Frade aquamarine deposit (Proctor, 1984, see figure 4). Again, all of the stages of pegmatite decomposition, erosion, and dispersal are represented in this one Santa Rosa hillside.

The Santa Rosa Gems. Although this mine produced attractive, rose-colored stones of the same fine quality as the Golconda mine previously discussed, it is noted particularly for the superb "watermelon" tourmaline found there (again, see figure 10). Spectacular crystals, $10-25 \mathrm{~cm}$ long $(4-10$ in.), with cores of rose-colored or red gem tourmaline surrounded by a sheath of superb green gem tourmaline were found in abundance at Santa Rosa. It is probably due to these crystals that the term watermelon became associated with the Santa Rosa mine. Some of the multicolored tourmalines from this deposit also exhibit a gemmy purple termination, while others include areas of blue as well as pink and green.

Most of the gem-quality crystals were used for cutting or carving, while many extremely large (some as long as $45 \mathrm{~cm}$ and weighing more than 20 $\mathrm{kg}$ ), spectacular, though nongem-quality crystals

Figure 12. At the time Dr. Fred Pough visited Santa

Rosa in June 1968, 452 tunnels had been driven into the hillside. Photo by Fred Pough.

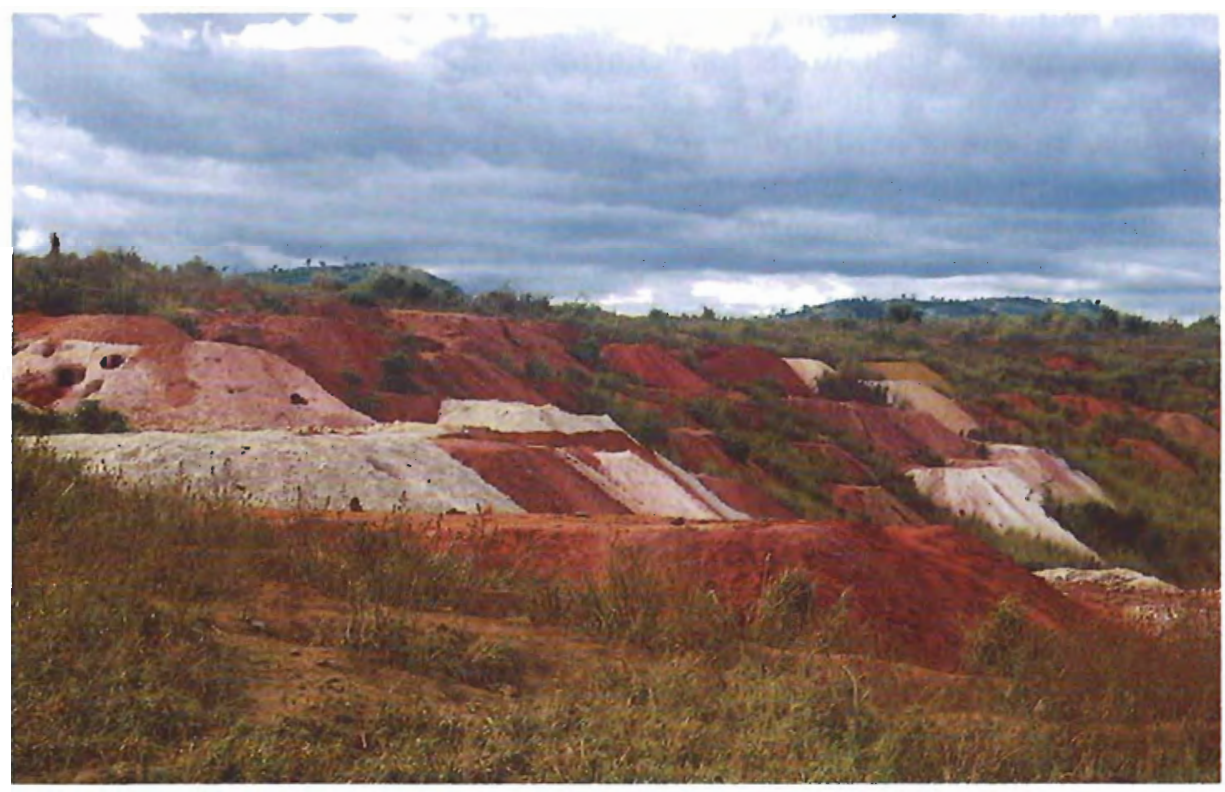


were sold as specimens. Some of these immense crystals can be seen in the Smithsonian Institution in Washington, DC, the American Museum of Natural History in New York, the Sorbonne exhibit in Paris, and the Folch Museum in Barcelona.

Many of the tourmaline crystals (usually about $2.5 \mathrm{~cm}$ in diameter) found in the colluvium at Santa Rosa had begun to decompose, leaving at least partially visible a flawless, rounded, gemmy, dark green central core. In some of these crystals, nugget-like cores called "balinhas," or "bullets," had been freed completely. In others, considerable skill with a hammer was required to tap the weathered prisms, or "canudos," just right in order to free the highly prized "balinhas" inside. Many of these nugget-like cores of dark green tourmaline represent some of the best rough found at Santa Rosa (Pough, 1968b).

Production. Despite the hit-and-miss mining, the yield of clean and near-clean multicolored crystals from this mine was tremendous. Levon Nercessian, a frequent visitor to the Santa Rosa mine, estimates that at least $500 \mathrm{~kg}$ of clean, multicolored tourmaline and $200 \mathrm{~kg}$ of "balinhas" were found at Șanta Rosa within a year after Matias's initial find, plus an additional $1600 \mathrm{~kg}$ of specimen-quality material.

After only the first five months, mining activity dropped off dramatically. Within three years, the mine was essentially abandoned. Although it is likely, given the disorganized fashion in which the pegmatite was attacked, that many areas of the pegmatite remain untouched, the honeycomb of unstable tunnels makes mining at Santa Rosa both difficult and dangerous. It is interesting to speculate how many more gems would have been removed if the deposit had been worked lengthwise with a bulldozer from the top down, in the same manner as the Salinas mine (Proctor, 1985).

Since fall 1980, however, there has been some renewed activity at Santa Rosa and at four or five nearby hills. Everything found, even in the nearby deposits, is simply labeled Santa Rosa. A limited quantity of mostly fine green crystals (some as long as $15 \mathrm{~cm}$ ) have been produced, reportedly from the hard-rock, unaltered part of the pegmatite. A large pocket with superb collector crystals was discovered in the late fall of 1984 . One dealer recently purchased $625 \mathrm{~g}$ of superb "emerald"green tourmaline produced at Santa Rosa in 1985 (K. Elawar, pers. comm., 1985). Approximately 50

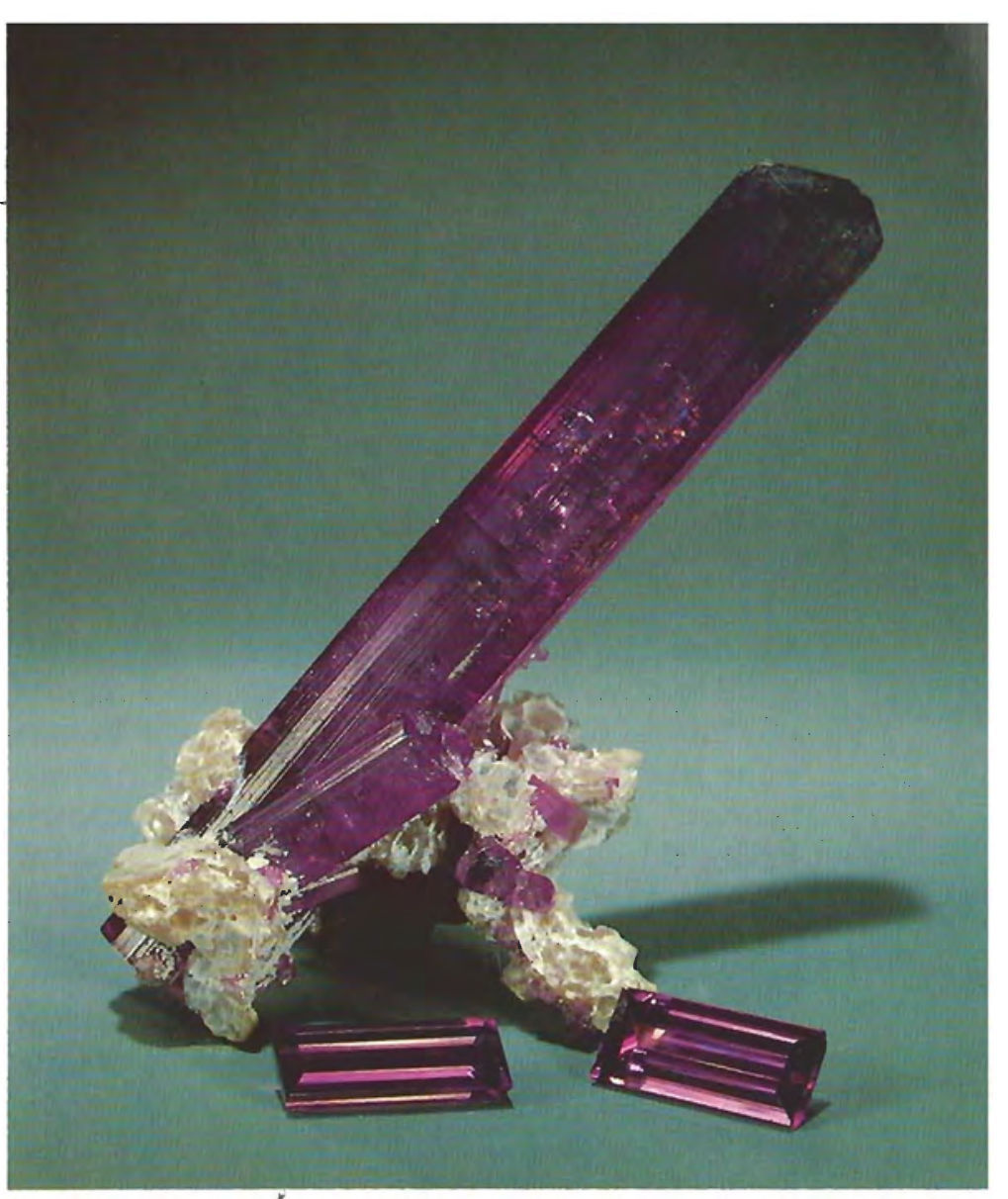

Figure 13. This 7.5-cm (3-in.) doubly terminated rubellite crystal with lepidolite matrix and the accompanying faceted stones 4 and $7 \mathrm{ct}$, respectively) represent some of the fine red tourmalines taken from the main pocket at the famous Jonas mine. Photo (C) Harold (4) Erica Van Pelt.

garimpeiros are working the area now, some by enlarging a number of the old hard-rock tunnels and others by opening new tunnels into the lessworked backside of the mountain. Considering its size and recent yields, Santa Rosa is one of the most promising mines in Brazil for future gem production.

\section{JONAS}

The Jonas mine, which represents the single most important rubellite discovery in the history of Brazil (figure 13), provides a fitting climax to our discussion of gem tourmalines in Minas Gerais. Not only is it the most recently discovered major gem deposit (1978), but its fascinating story is well documented, involving incredible hardships, tremendous good luck, natural hazards that had to be overcome, and unproductive mining that almost brought a halt to what eventually led to a rubellite bonanza greater than any known before or since.

The mine itself is not far from Governador Valadares and is only a few kilometers from the 
town of Conselheiro Pena (see figure 2). To reach the Jonas mine, take Highway 259, a good dirt road, from Governador Valadares $85 \mathrm{~km}$ (53 mi.) eastsoutheast to Conselheiro Pena. From there, a passable dirt road leads $4.8 \mathrm{~km}$ ( $3 \mathrm{mi}$.) southeast to the mine, which lies on the Itatiaia hillside overlooking the valley and stream of the same name.

History. The Itatiaia hillside encompasses one of the largest and most important pegmatite regions in Minas Gerais. For almost 50 years, the Itatiaia mine produced hundreds of kilos of multicolored "parrot" tourmalines; nearby alluvial deposits have yielded literally tons of green gem tourmaline over the years. The Jonas mine is within $1 \mathrm{~km}$ of the Itatiaia mine (now largely inactive), where garimpeiro Barbosa first found the famous "parrot $^{\prime \prime}$ tourmalines in the early 1930s. The present story, fittingly enough, involves as one of its principal characters garimpeiro Ailton Barbosa, his son. Most of the following account was told to the author by Ailton Barbosa.

The hard-rock pegmatite body now known as the Jonas mine was first tunneled by a local farmer, João Pinto, in the early 1940s. For several years it produced superb four- and five-colored pristine crystals up to $12 \mathrm{~cm}$ (4.75 in.) long (E. Swoboda, pers. comm.; Bancroft, 1984).

The Ionas pocket. The modern history of the Jonas mine (previously called the João Pinto mine) began to unfold in 1977, when Ailton Barbosa told wellto-do gem dealer Jonas Lima of Governador Valadares of his determination to one day mine Itatiaia as his father had done and find many fabulous gems. Ailton, also a gem dealer, invited Jonas along on one of his buying trips to Itatiaia and introduced him to the rancher-owner of the Itatiaia hillside that Ailton had coveted for so many years. The land owner knew Ailton and agreed to lease the mine to Jonas, who was to put up all the operating capital, on condition that Ailton would supervise the mining. The lease payment was only 1,000 cruzeiros (roughly US\$70) per month; the land owner did not insist on a percentage of royalties on any gems found.

With his crew of only four garimpeiros, Ailton started mining in October 1977 by extending an existing short tunnel horizontally into the enclosing schist and pegmatite. They worked four months with little success, finding only some matchstick-sized green tourmalines attractively arranged on 5-cm white albite crystals (Lallemant, 1978). In early February 1978, they finally penetrated several large pockets, but all they removed were three tons of worthless black tourmaline crystals mixed with albite.

Ailton and Jonas stopped working together for awhile after this disappointing start, but later Jonas went to Ailton and asked that they try again.

On the first of April, after six months of fruitless and expensive blasting and digging, and only a week before the big discovery, a discouraged Jonas told Ailton he wanted to call it quits; he would not go on without some financial support (Huber and Huber, 1980). Ailton, who has more faith than any other garimpeiro the author has ever known, had found occasional patches of lepidolite-the best overall indicator of gem tourmaline-in the pegmatite wall. Ailton told Jonas three times that they must go on, and promised Jonas what appeared to be a wild fantasy: "a huge gem pocket and rubellites as thick as his forearm." Ailton later confided that he didn't know that much about rubellites at the time and had never seen one that big, but he had a very strong premonition that he would find such crystals. Jonas was to find Barbosa's description of the crystals incredibly accurate.

After drilling and blasting through $30 \mathrm{~m}$ of schist and only a few meters of pegmatite, Ailton, only a few days away from the big discovery, finally blasted into a second big pocket-again containing large, worthless crystals of opaque black tourmaline with opaque pink tops and albite mixed with mud, water, and much quartz and mica. Ailton was near financial exhaustion himself, but the $25-\mathrm{cm}$ ( $10 \mathrm{in}$.) black and pink crystals encouraged him to go on. Ailton even surrendered the title to his Volkswagen to raise the money for food and mining for just one more week; he promised Jonas that when the food and the dynamite ran out, he would finally abandon the mine.

As Ailton laboriously cleaned out this worthless chamber, he felt certain that the water entering from above indicated the existence of another pocket. So Ailton directed the excavation upward and, using hand digging and only partial sticks of dynamite, he carefully engineered an opening big enough to thrust his arm through into the area from which the water was draining. This was on Good Friday, 1978, and as he first reached his arm into the hole and groped above in the darkness, his and Jonas's lives were forever changed. For when 
he brought his hand out it contained a large, almost flawless, gem rubellite crystal. He then flashed his brightest mining light in to the hole and revealed an immense cavern, its walls sparkling with the red of gem rubellites (figure 14).

Ailton and his four fellow garimpeiros immediately closed the small hole. Ailton rushed to Conselheiro Pena and telephoned Jonas in Governador Valadares. Matter-of-factly, he told him: "I found the gems, COME ON DOWN."

After Jonas arrived, they began digging another route into the pocket, since they had first entered it through the bottom. They dug all night and most of the next day; with great anticipation they finally reached the pocket again. They were flabbergasted to find that the pocket was so big that they could walk right into it-with rubellites and albites crunching underfoot.

Imagine the gem pocket-an oval $3 \mathrm{~m}$ (10 ft.) high, $3 \mathrm{~m}$ long, and $2.5 \mathrm{~m}$ (8 ft.) wide-uniformly lined with rubellite crystals interspersed with just three other minerals: snow-white albite, transparent quartz, and pink lithium-bearing lepidolite mica (see figure 14). These three finely crystallized minerals provided the matrix into which the gem rubellites were nestled on the walls. Some of the rubellites had fallen, but most were intact. Many were doubly terminated-another rarity. Among the multitude of great surprises was the fact that the pocket was almost totally clean; virtually no chemical alteration had occurred. There was only a little sand mixed with the albites and rubellites on the floor, and the specimens were so clean that they did not even need to be washed. The elation and awe these men felt is beyond description. Lying before their eyes was the richest, most valuable, and certainly most stunning pegmatite gem pocket ever seen by man. Only Jonas knows how many millions of dollars lay there within his grasp. This pocket became known worldwide as the bamburrio (jackpot) pocket, and quickly claimed its place in gemstone lore.

Standing out among this richness was a fabulous matrix gem crystal specimen that hung precariously from the ceiling. This specimen, later named Joninha ("small Jonas," after Jonas's young son) consists of two gigantic rubellite crystals $50 \times$ $25 \mathrm{~cm}$ and $25 \times 30 \mathrm{~cm}(20 \times 10 \mathrm{in}$. and $10 \times 12 \mathrm{in}$. growing on two quartz crystals $20 \mathrm{~cm}$ and $45 \mathrm{~cm}$ long. The specimen is partially coated with albite; a $20-\mathrm{cm}$ (8 in.) doubly terminated pale citrine crystal hangs on the side of the largest rubellite.
The Joninha specimen, which with its massive matrix weighs $352 \mathrm{~kg}(775 \mathrm{lbs}$ ), had been partially dislodged from the wall-probably by the small dynamite charges. The miners could fit their hands behind part of the specimen. This masterpiece of the gem kingdom was about to fall.

Lying broken on the floor were three pieces of a gigantic rubellite crystal that, when glued back together, soared $107 \mathrm{~cm}$ (more than $3 \frac{1}{2} \mathrm{ft}$.) from a matrix of doubly terminated $35-\mathrm{cm}$-long quartz crystals. This specimen, the largest known rubellite crystal, was named the Rocket. It weighs 135 $\mathrm{kg}$ (300 lbs.) and is mostly opaque (not suitable for cutting). The broken edges of the three pieces had been rehealed by minute tourmaline growth yet still fit together perfectly; even though a few pieces were missing when the specimen was repaired, it is stunning (see figure 15).

Also lying on the floor was the opaque rubellite crystal named Tarugo ("a short, fat, ugly

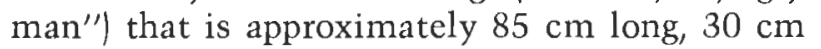
wide, and weighs $82 \mathrm{~kg}$ (180 lbs.).

The fourth great specimen they noted was the Fleur de Lis, a $35-\mathrm{cm}$ tourmaline attached to a $60-\mathrm{cm}$ quartz crystal and, unfortunately, $65 \%$ covered with albite. Many of the smaller gem crystals on the walls and ceilings were surrounded by intricate clusters of small, gemmy, pink lepidolite crystals (again, see figure 13).

Understandably, Jonas required a large dose of Valium to calm down. After their whoops and hollers had subsided, the miners decided their first order of business was to save the Joninha. Ailton came up with the idea of piling old tires up from the floor to just below the specimen and covering the topmost tires with a burlap pad. With miners pushing upwards on all sides, a final pry with the crowbar released the Joninha gently onto the tires. Miraculously, it left the mine and reached Governador Valadares that night without damage, even though Ailton fell asleep at the wheel, missed a curve, and drove the Jeep down a $20-\mathrm{m}$ embankment.

What happened next as they started to clean out this incredible pocket has become legendary in the gem and mineral community around the world. Jonas's first concern was the security for his valuable cache. The history of Brazil's "wild West" closely parallels that of our own, except that the land wars, lawlessness, and gunfights in Governador Valadares climaxed only in the mid-1950s when a very valiant man, a Colonel Pedro, brought 


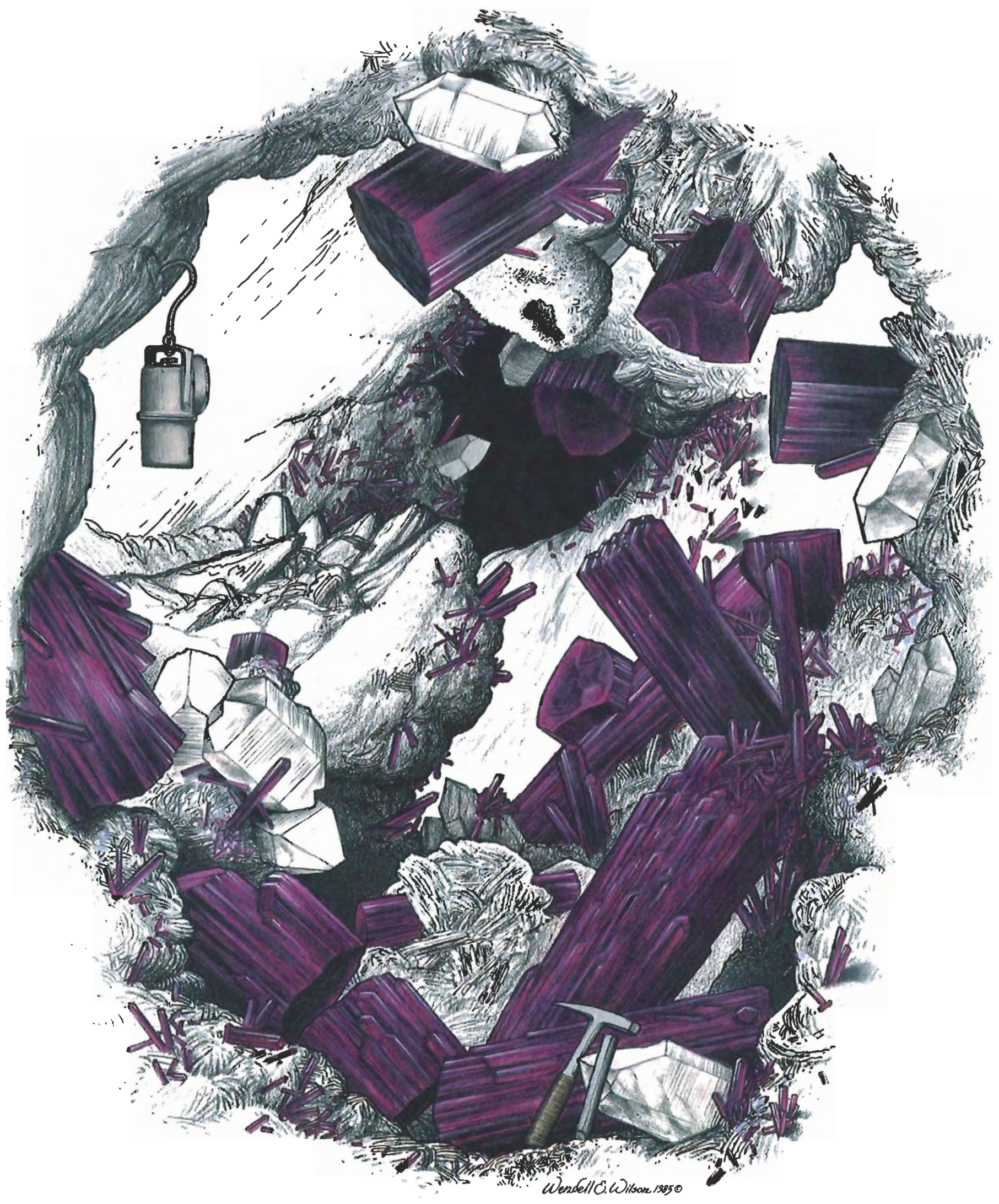


Figure 14. Artist's conception of how the Jonas mine pocket may have looked when first discovered. The reconstruction is based on photos and measurements of some of the major pieces, and on interviews with the original miners regarding the location of specimens within the pocket. The pocket measured $2.5 \times 3 \times 3 \mathrm{~m}(8 \times$ $10 \times 10 \mathrm{ft}$.); the specimens are drawn approximately to scale. Rendering courtesy of Wendell E. Wilson.

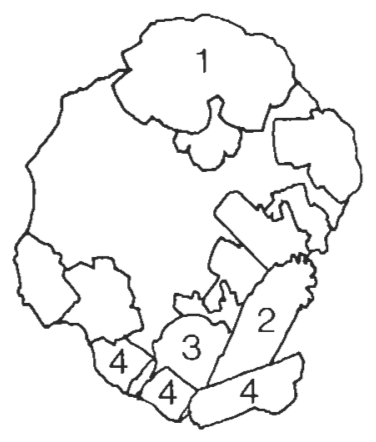

1. Joninha

2. Tartigo

3. Fleur de Lis

4. The Rocket

the army into the region and exterminated the outlaws (A. Lucio, pers. comm.; Caplan and Wilson, 1980). Jonas is Pedro's son-in-law, so it wasn't hard for him to find old-time gunfighters who were willing to help with security while loving the drama and importance of the event, which rekindled the excitement of that earlier era.

In only eight days this first pocket was completely cleaned out and the crystals, under a guard befitting the crown jewels, were transported $90 \mathrm{~km}$ to Governador Valadares. Eventually both the mine entrance and the warehouse in Governador Valadares where the gems were stored were declared off-limits to photographers and most other people. These two regions became armed camps. It even became difficult for gem dealers and crystal collectors to view the material and, when viewing was allowed or sales were made, armed guards were visible everywhere. Even Brazilian Internal Revenue agents were unsuccessful in their attempts to examine the discovery (Lallemant, 1978). According to Wilson and Barreto (1978), the Rocket and other specimens under guard at the warehouse sat on tables supposedly wired to dynamite stacked underneath. Jonas threatened that if robbers or revenuers came around he would blow the whole thing up-evidently he would have been satisfied with melee. When Jonas gave the author the honor of viewing the four major specimens in the summer of 1980, he quoted the total value of all four at US $\$ 9,000,000$. Jonas eventually started charging $\$ 8.00$ per person just to see the four major pieces (Huber and Huber, 1980).

For the remainder of the specimens,. Jonas chose as his agent one of the best salesmen and most colorful characters in the region, João das Moças (John of the girls), who is notorious for having seven wives - all at the same time. John eventually made enough money to buy a house for each of them.

The Second Pocket. Within three months of the first discovery, Jonas had a disagreement with the land owner over the lease of the mine, and by late July 1978 he had abandoned the operation. He also dynamited the tunnel shut about $30 \mathrm{~m}$ inside the entrance and left a wheelbarrow full of unstable, decomposing dynamite nearby (Keller, 1979).

Figure 15. The Jonas mine specimen known as the Rocket is believed to be, at $107 \mathrm{~cm}$ (more than 31/2 $f t$.), the largest rubellite crystal ever found.

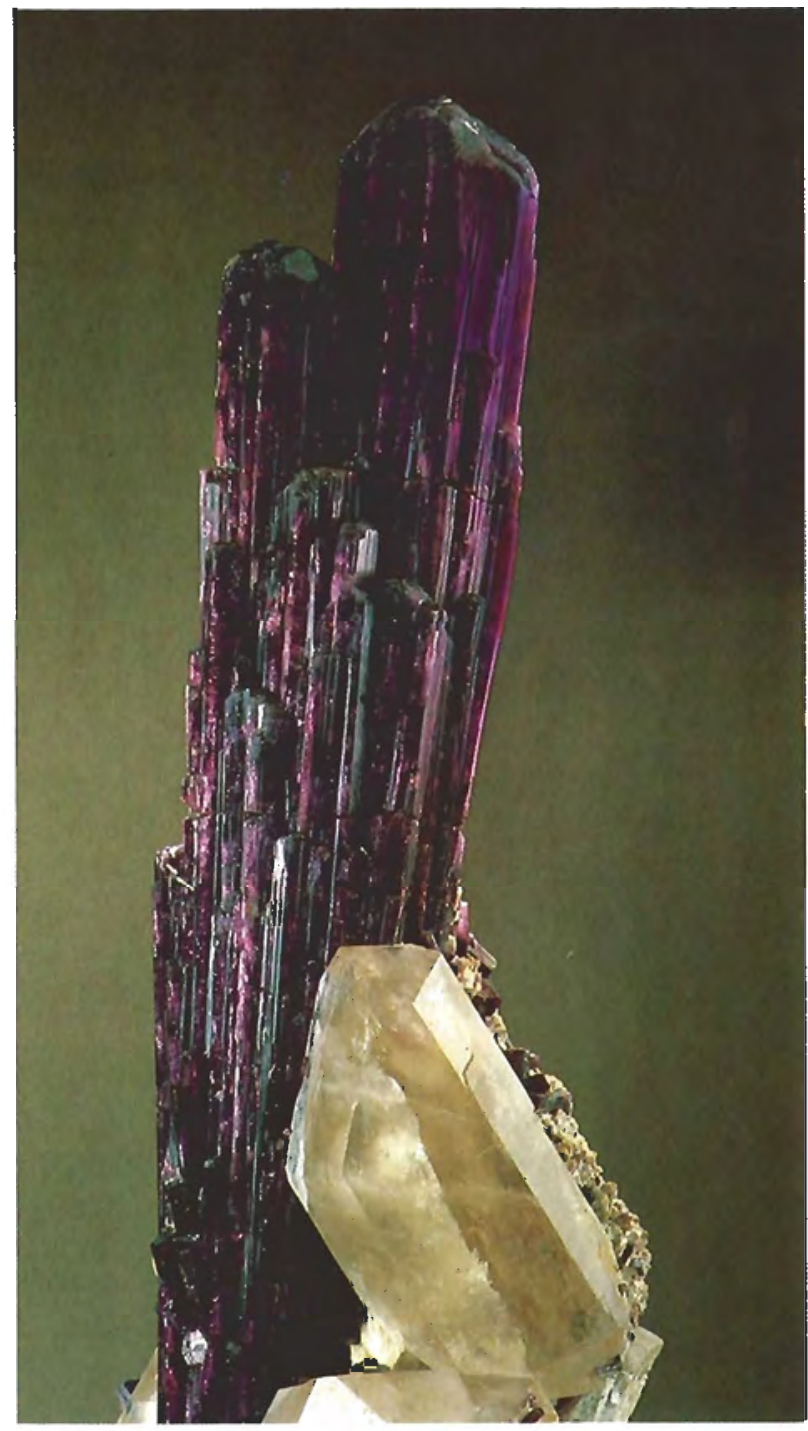


However, a large adit intersected the pegmatite about $50 \mathrm{~m}$ above the closed tunnel, allowing an alternate entrance into the workings.

A new lessee, Dilermando de Melo ("Dilo") began mining immediately. In the ensuing two years, he opened a tunnel $130 \mathrm{~m}$ long. A few insignificant pockets with small dark green tourmalines on white albite were opened, and occasional rubellite specimens were found, but nothing truly exceptional was recovered during the first several months (Huber and Huber, 1980; Lucio, 1980). Surprisingly, Dilo found quite a few excellent gem blue tourmaline crystals in this region of the pegmatite. Then, in early April, a year after the first pocket discovery, Dilo and his miners encountered all the signs of another great find.

Working down through the pegmatite, they struck the outer wall of what appeared to be a large pocket, right beneath their feet on the floor of the tunnel. Quickly they set off the dynamite charge to open the pocket, and Dilermando, in his excitement, neglected to allow the necessary time for the gasses to disperse. He went directly to the blast site and, leaning over to look into what he hoped was another Jonas pocket, was immediately overcome with the fumes from the explosion. His foreman took him to the hospital, and Dilermando lay there impatiently waiting to be well enough to return and find out what his last charge of dynamite had revealed. When Dilo was released from the hospital, he and his partner went immediately to the mine. Coincidentally, Good Friday, 1979, again brought a choice discovery. The pocket was not yet open completely. Still remaining to be penetrated was a thin, $7.5-\mathrm{cm}$ ( 3 in.) layer of albite from the inner pocket wall. With picks and crowbars, they pried and finally broke loose a $45-\mathrm{cm}$ almost-square piece of this inner wall. With one person on each side, they carefully removed the section, fortunately by lifting straight up. When they turned it over, there on the other side of the piece was the beautiful Rose of Itatiaia, shown in figure 1 .

This gem pocket, completely filled with moist sand, was a 2- to $2.5-\mathrm{m}$ ( 6 to $8 \mathrm{ft}$.) oval inside; like the Joninha, the Rose was hanging upside down, suspended from the ceiling of the geode-like pocket. Surprisingly, this was the only rubellite specimen in this second huge gem pocket. So ends the saga of the Jonas rubellite mine. To this day, no other major rubellites have been found. Although considerable pegmatite remains, there is little ac- tivity in the area as of this writing because of the expense of mining this deposit.

The Rose of Itatiaia specimen is somewhat brighter in color than those of the first pocket (Huber and Huber, 1980). This $35 \mathrm{~cm}$ (14 in.) long by $12 \mathrm{~cm}$ (5 in.) wide gem rubellite crystal is nestled in a bed of gemmy albite crystals. The author acquired the Rose of Ita tiaia in the summer of 1980, and several articles have been written about the harrowing odyssey this specimen went through before it finally arrived safely in Colorado (Zeitner, 1981 and 1983; Jones, 1982).

The survival undamaged of the Joninha and the Rose of Itatiaia as well as other major gem crystals from this and other great gem mines is truly remarkable. Not only did they withstand the violent conditions of changing heat, pressure, and earth movements under which they were created, but they also survived the trauma of dynamite and removal at the hands of the miners.

The Joninha was eventually sold to a private party in the United States for US $\$ 1,300,000$; the Rocket was subsequently acquired for the same mineral collection.

Occurrence. According to Ailton Barbosa, the pegmatite that housed these tremendous finds is $12 \mathrm{~m}$ wide and $200 \mathrm{~m}$ long as it snakes its way nearly horizontally through the hillside in a $\mathrm{N} 30^{\circ} \mathrm{E}$ direction. Therefore, it is only one-fourth as long as the three Cruzeiro pegmatites and only a small fraction of their overall width. Jonas worked only $30 \mathrm{~m}$ of the pegmatite.

Sharp crystals of cassiterite, pink apatite, and the rare mineral microlite were found in the pegmatite. Unusually sharp microcrystals of monazite were also frequently found. It is significant to note that no muscovite mica or microcline was found in either of the two great Jonas mine pockets. Also, as might be expected from all the rubellite present, spessartine garnets were found on the dumps by the author; these were wafer-thin and were squashed between large muscovite mica sheets from the pegmatite body and not the Jonas pocket.

There are many other gemstone mines in this rich Itatiaia pegmatite district, including alluvial tourmaline deposits and mines that were producing highly etched but attractive beryl crystals at the same time as the Jonas mine discovery (Keller, 1979|. However no aquamarine, topaz, or spodumene was found in the Jonas mine. 
Production. The original Jonas pocket yielded, at best estimates, at least $200 \mathrm{~kg}$ (450 lbs.) of finequality cuttable crystals of an exceptional "cranberry," or deep magenta-red, color. One crystal alone cut a million dollars (retail) worth of gems. Additionally, approximately $3,600 \mathrm{~kg}(8,000 \mathrm{lbs}$.) of specimens (rubellite with matrix) were removed (Keller, 1979). Both foreign and local experts agreed that this was the single most important find of tourmaline in history.

Because so many of the crystals were fat, even large gemstones could be cut perpendicular to the c-axis. The finished gems were dazzling in color, brightness, and fire (Lallemant 1978). Keller (1979) said they were among the finest rubellites known. In this author's opinion, however, even the best red tourmalines from the Jonas mine are not as good as the very finest "cherry"- and "ruby"-red stones to come from the Ouro Fino or Cruzeiro mines.

As is the case with other rubellites, flawless stones from Jonas material are rare, but their extraordinary, cranberry color far outweighs their ever-present inclusions. As is usually the case with fine rubellite, gemstones cut from the Jonas material were absorbed in to the market quickly. In less than two years, they were already in short supply.

\section{OTHER MINES IN THIS REGION}

In the general region between the Araçuaí and Governador Valadares districts, deposits of fine tourmaline have been found in varying frequency in areas surrounding the cities of Turmalina, Minas Novas, Capelinha, Poté, and Itambacurí, with the best gems having come from Novo Cruzeiro (see map, figure 2, in Proctor, 1984). It is safe to say that the Cruzeiro-Aricanga, the JonasItatiaia, the three Golcondas, and the Santa Rosa have produced a higher dollar value of fine gems than all the rest of the mines in the Governador Valadares district combined. However, many other smaller but important deposits in this district have been mined and deserve mention.

Near the Cruzeiro, the Marcello mine has produced some of the finest blue stones ever found in Brazil. The nearby Chiá and Urupuca mines, also produced fine blue stones. The mines around the town of Galiléia, such as Pedra Alta, Laranjeiras, Divino, Ferruginha, and Retiro, have produced fine green, blue-green, and rose material. In the Golconda region, yellow-green, fine blue, and gold tourmalines have been recovered from the Faria, Jacob, and Lavra Faria mines, respectively. The Pammarole and Linopolis mines near the city of Linopolis are known for their fine red material (Bank, 1970). Other notable tourmaline deposits are indicated on the map in figure 2.

\section{SUMMARY AND CONCLUSION}

Minas Gerais, Brazil, is the largest producer of gem tourmalines in the world. The pegmatites in the northeastern area of this state have yielded literally millions of carats of tourmalines of virtually every color variety. Twenty important mines were discussed in the preceding article in this series, on the Araçuai districts (Proctor, 1985). Although the present article focused on only four localities, these four include some of the oldest and most productive mines in Minas Gerais.

Cruzeiro (including the Aricanga Companyowned mine) and Golconda (I, II, and III mines) represent two of the largest known pegmatite deposits in Brazil. They have consistently produced gem- and specimen-quality tourmalines for more than 30 years. While Cruzeiro has yielded large quantities of fine blue-green, green, blue, pink and "watermelon" tourmalines, the rubellite found there is considered among the best in Brazil. All three Golconda mines have produced tourmaline over the years, but the most important find $1900 \mathrm{~kg}$ of "emerald"-green gem tourmaline, as well as significant deposits of green "pencils" and distinctive bicolored crystals| was made at Golconda III. Golconda II is now the most active of the three mines and is noted as a sporadic producer of green, blue-green, and rose tourmalines as well as small amounts of spectacular blue gems. Now undergoing renovation, it promises to be the most productive of the three Golconda mines in the future.

In the space of a year, the Santa Rosa mine yielded an estimated $2300 \mathrm{~kg}$ of gem- and specimen-quality tourmaline, primarily multicolored crystals. But as quickly as the Santa Rosa hill was entered, it was virtually abandoned. For more than 10 years after the initial 1967 find, there was almost no activity at Santa Rosa. The renewal of mining since 1980 has produced small quantities of gem material, but nothing on the scale of the original bonanza.

The Jonas mine produced the largest and most valuable deposit of fine gem rubellite ever found in one pocket and possibly in one mine. Not only was this the cleanest and least altered chemically of 
the large gem pockets with which the author is familiar, but it was also possibly the largest open gem pocket on record. Five of the largest and finest gem rubellite crystals ever found were produced in this one mine. In addition, hundreds of thousands of carats of gems were cut. After the original discoveries, however, there were no additional major finds. Because of the expense of mining the hardrock pegmatite, the legendary Jonas mine is now essentially abandoned.

Of the 30 best-known tourmaline mines in this district, only four are sporadically producing, and two others - the Cruzeiro and the Aricangaare responsible for $90 \%$ of the present production.
Author's Note: I wish to especially thank the following people for allowing me to visit their mines (indicated here in parentheses) and take the many photos needed for this series of articles: Dr. Rex Nash (Marambaia Valley); Inacio Moura Murta (Frade mine); José de Estrada (Jenipapo and Piauí deposits); Servio Getulio Ursine (Virgem da Lapa); Halley Freire Batista (Salinas); Francisco Freire Murta and Wilson Freire Murta (Ouro Fino mine); José Neves (Cruzeiro mine); Frank Davis and Celso Cravinhoff (Golconda mine); Iosé Gomez da Rocha (Santa Rosa mine); Ailton Barbosa, Jonas Lima and Dilermando Rodrigues de Melo (Jonas mine); Agenor Tavares and Henry F. Kennedy (Corrego do Gil and Barro Preto); and Neylson Barros (Corrego do Urucum).

\section{REFERENCES}

Baker E. (1975) A gem and mineral tour. Lapidary Journal, Vol. 29 , No. 2, pp. 496-507.

Bancroft P. (1984) Gem and Crystal Treasures. Western Enterprises and Mineralogical Record, Fallbrook, CA

Bank H. (1970) Mineralfundstellen in der Umgebung von Governador Valadares in Minas Gerais, Brasilien, Der Aufschluss, Vol. 21, No. 1, pp. 47-54.

Bank H. (1979) Edelsteine aus Brasilien. Zeitschrift der Deutschen Gemmologischen Gesellschaft, Vol. 28, No. 1, pp. $21-34$.

Barbosa A.L. de M. (1944) Mica em Governador Valadares. Mineraçdo e Metalurgia, Vol. 8, No. 43, pp. 29-34.

Caplan A., Wilson W. (1980) Intervicw: Allan Caplan. Mineralogical Record, Vol. 11, No. 6, pp. 351-366.

Cassedanne J.P., Sauer D.A. (1980) Famous mineral localities: the Cruzeiro mine past and present. Mineralogical Record, Vol. 11, No. 6, pp. 363-370.

Gonsalves A.D. (1949) As Pedras Preciosas na Economiz Nacional. Gráfica Olímpica Editora, Rio de Janeiro.

Huber P., Huber S. (1980) Rubellit aus Brasilien. Lapis, Vol. 5, No. 1, pp. $28-31$.

Jones B. (1982) The dream collection. Rock \&) Gem, Vol, 12, No. 8 , pp. $28-32$.

Keller P.C., Kampf A.R. (1977) The Natural History Museum of Los Angeles County: out of the past and into the future. Mineralogical Record, Vol. 8, No. 6, pp. 487-492.

Keller P.C. (1979) More on rubellite from the Itatiaia mine, Brazil. Mineralogical Record, Vol. 10, No. 1, pp. 33-34.

Lallemant A. (1978) What's new in minerals. Mineralogical Record, Vol. 9, No. 5, pp. 298-299.

Lucio A. (1980) Review of history and survey of present and future mining in Brazil. Report at the 7th Annual Rochester Mineralogical Symposium, Rochester, New York (unpublished).

Murdock T.G., Hunter C.E. (1944) Mica na região de Santa

Maria do Suassuí Estado de Minas Gerais. Avulso, No. 53, Rio de Janeiro.

Ottoni A.B., Noronha F. (1942) Jazida de mica do "Cruzeiro," Minas Gerais. Mineraçao e Metalurgia, Vol, 6, No. 34, pp. $169-170$.

Pecora W.T., Klepper M.R., Larrabee D.M., Barbosa A.L. de M., Frayha R. (1950a) Mica deposits in Minas Gerais, Brazil: geologic investigation in the American Republics, 1949. U.S. Geological Survey Bulletin, \#964-C, pp. 205-305.

Pecora W.T., Switzer G., Barbosa A.L. de M., Myers A.T. (1950b) Structure and mineralogy of the Golconda pegmatite, Minas Gerais, Brazil. American Mineralogist, Vol. 35, No. 9/10, pp. 889-901.

Pough F.H. (1968a) The Santa Rosa gem rush fizzles out. Jewelers' Circular-Keystone, Vol. 139 , No. 2, pp. 56,70-74.

Pough F.H. (1968b) The Santa Rosa, Brazil tourmaline mine. Lapidary lournal, Vol. 22, No. 7, pp. 890-895.

Proctor K. (1984) Gem pegmatites of Minas Gerais, Brazil: exploration, occurrence and aquamarine deposits. Gems et) Gernology, Vol. 20, No. 2, pp. 78-100.

Proctor K. (1985) Gem pegmatites of Minas Gerais, Brazil: the tourmalines of the Araçuaí districts. Gems et) Gemology, Vol. 21, No. 1, pp. 3-19.

Sauer D.A. (1975) Levantamento geologico da jazida do Cruzeiro. Graduation Report, The Geological Institute of the Federal University of Rio de Janeiro, Rio de Janeiro, Brazil (unpublished).

Shigley J.E., Kampf A.R. (1984) Gem-bearing pegmatites: a review. Gems \&) Gemology, Vol. 20, No. 2, pp. 64-77.

Wilson W., Barreto L. (1978) Editor's note. Mineralogical Record, Vol. 9, No. 5, p. 298.

Zeitner J.C. (1981) A new competitor for "the world's finest specimen" to be unveiled at the 1981 Tucson Gem and Mineral Show. Lapidary Journal, Vol. 34, No. 10, pp. 2210-2211.

Zeitner J.C. (1983) Proctor's rough-and-cut collection. Lapidary Journal, Vol. 37, No. 4, pp. $572-576$. 